\title{
$\beta$ - and $\delta$-Amino acids (2,3- and 3,4-trans-CHA) as catalysts in Knoevenagel condensation and asymmetric aldol reactions
}

\section{Lo'ay Ahmed Al-Momani, ${ }^{a}$ Volker Lorbach,,${ }^{b, c}$ Jean Detry, ${ }^{b}$ Petra Geilenkirchen, ${ }^{b}$ and Michael Müller*d}
${ }^{a}$ Tafila Technical University, Department of Chemistry, Tafila P.O. Box 179 (66110), Jordan
${ }^{b}$ IBG-1: Biotechnology, Forschungszentrum Jülich GmbH, 52425 Jülich, Germany
${ }^{c}$ Present address: ISERA GmbH, 52355 Düren, Germany
${ }^{d}$ Institute of Pharmaceutical Sciences, Albert-Ludwigs-Universität Freiburg, Albertstrasse 25, 79104 Freiburg, Germany
E-mail: michael.mueller@pharmazie.uni-freiburg.de

\section{DOI: $\underline{\text { https://doi.org/10.24820/ark.5550190.p009.854 }}$}

\begin{abstract}
The efficacy of the $\beta$ - and $\delta$-amino acids (5S,6S)-6-amino-5-hydroxycyclohexa-1,3-dienecarboxylic acid (2,3-trans-CHA) and (3R,4R)-4-amino-3-hydroxycyclohexa-1,5-dienecarboxylic acid (3,4-trans-CHA) as catalysts in Knoevenagel condensation and aldol addition reactions is studied. Synthesis of the zinc(II) complexes of 2,3- and 3,4-trans-CHA provided precipitated material of sufficient purity for use. The catalytic Knoevenagel reactions were carried out with the $\beta$-amino acid 2,3-trans-CHA and the $\delta$-amino acid 3,4-trans-CHA, resulting in a product yield of up to $61 \%$. The asymmetric aldol addition reactions were carried out with catalytic amounts of the zinc(II) complexes of 2,3- and 3,4-trans-CHA. In this case, it was observed that the ee of the product (up to $90 \%$ ) depends on the conversion and/or the reaction time.
\end{abstract}

Keywords: Organocatalysis; chemoenzymatic synthesis; synthetic biology; diversity-oriented synthesis; chorismate; shikimate

\section{Introduction}

Organocatalysis has attracted the attention of many synthetic chemistry groups worldwide. Indeed, the beginnings of organocatalysis can be traced back to early in the nineteenth century. ${ }^{1,2}$ In 1909 , Dakin reported the organocatalytic behavior of some naturally occurring amino acids, peptides and proteins in aldol reactions. ${ }^{3}$ Additionally, it was noted that primary amines catalyze the decarboxylation of $\alpha$-ketocarboxylic acids to produce the corresponding aldehydes. ${ }^{4,5}$ In 1953 , Prout reported the catalytic effect of L- and D-amino acids as well as the catalytic behavior of $\beta$ - 
amino acids in Knoevenagel condensations; good yields were achieved using $\beta$-alanine as a catalyst. $^{6}$

In the 1970s, L-proline was introduced as a catalyst in the asymmetric Robinson annulation reaction. ${ }^{7,8}$ It is now established as a chiral organocatalyst and as a source of chirality in the syntheses of many products. ${ }^{9,10}$ Several aspects were taken into consideration in the development of L-proline as a catalyst, including its small size, rigidity, inexpensiveness and ready availability. ${ }^{9}$ This secondary amine has been used as a catalyst in intermolecular aldol reactions. ${ }^{11-15}$ It has been proposed that proline catalyzes the aldol reaction according to a mechanism involving an enamine intermediate. ${ }^{16}$ This provides hydrogen bonding between the carboxylic acid group of proline and the carbonyl group of the substrate. ${ }^{7,8,17-19}$ A stereoselective Mannich reaction has also been achieved using L-proline catalysis. ${ }^{19-21}$

The use of primary amino acids as chiral catalysts has been thoroughly studied and improved within the past decade. ${ }^{22-25}$ In 2005, Amedjkouh reported the L-valine-catalyzed intermolecular aldol addition of acetone with aromatic aldehydes; sufficient yields and enantiomeric excesses were achieved. ${ }^{26}$ Other natural primary amino acids were also used. ${ }^{27-29}$ Cordova and co-workers have reported that primary amino acids serve as powerful organocatalysts in intermolecular aldol reactions of cyclic ketones. ${ }^{30-32}$

We were intrigued by the idea of using nonproteinogenic, yet natural, primary $\beta$ - and $\delta$-amino acids as catalysts. (5S,6S)-6-Amino-5-hydroxycyclohexa-1,3-dienecarboxylic acid (2,3-transCHA, 2) and (3R,4R)-4-amino-3-hydroxycyclohexa-1,5-dienecarboxylic acid (3,4-trans-CHA, 4) (Scheme 1) are nonproteinogenic primary amino acid metabolites of the shikimate pathway ${ }^{33}$ and are accessible through metabolic engineering of recombinant E. coli strains. ${ }^{34}$ The shikimate pathway is an instructive example of diversity-oriented biosynthesis of a wide spectrum of natural products (Scheme 1). ${ }^{35,36}$ Shikimate- and chorismate-derived metabolites and their enzymatic transformations have been applied in synthesis, notably by Frost et al. ${ }^{37}$ and by Müller et al. ${ }^{38-42}$ These multifunctionalized and conformationally restricted natural products could serve as valuable chiral auxiliaries, chiral ligands, and organocatalysts in asymmetric transformations. Here, we focus on the production of the microbial nonproteinogenic amino acids 2,3-trans-CHA and 3,4trans-CHA (4), and derivatives thereof, and their use as potent (organo)catalysts.

\section{Results and Discussion}

The aim of this study was to prove the efficiency of the $\beta$ - and $\delta$-amino acids 2,3-trans-CHA (2) and 3,4-trans-CHA (4) as catalysts in Knoevenagel condensation and asymmetric aldol addition reactions. The reference compound in this work was the proteinogenic amino acid L-proline (6), which was used as an organocatalyst in its pure form and as the zinc(II) complex in Knoevenagel and aldol reactions, respectively. 
L-Proline (6) is a secondary $\alpha$-amino acid, while $\mathbf{2}$ and $\mathbf{4}$ are primary $\beta$ - and $\delta$-amino acids, respectively. L-Proline and both the amino alcohols $\mathbf{2}$ and $\mathbf{4}$ are chiral, and all three possess conformational restrictions with somewhat rigid structures.

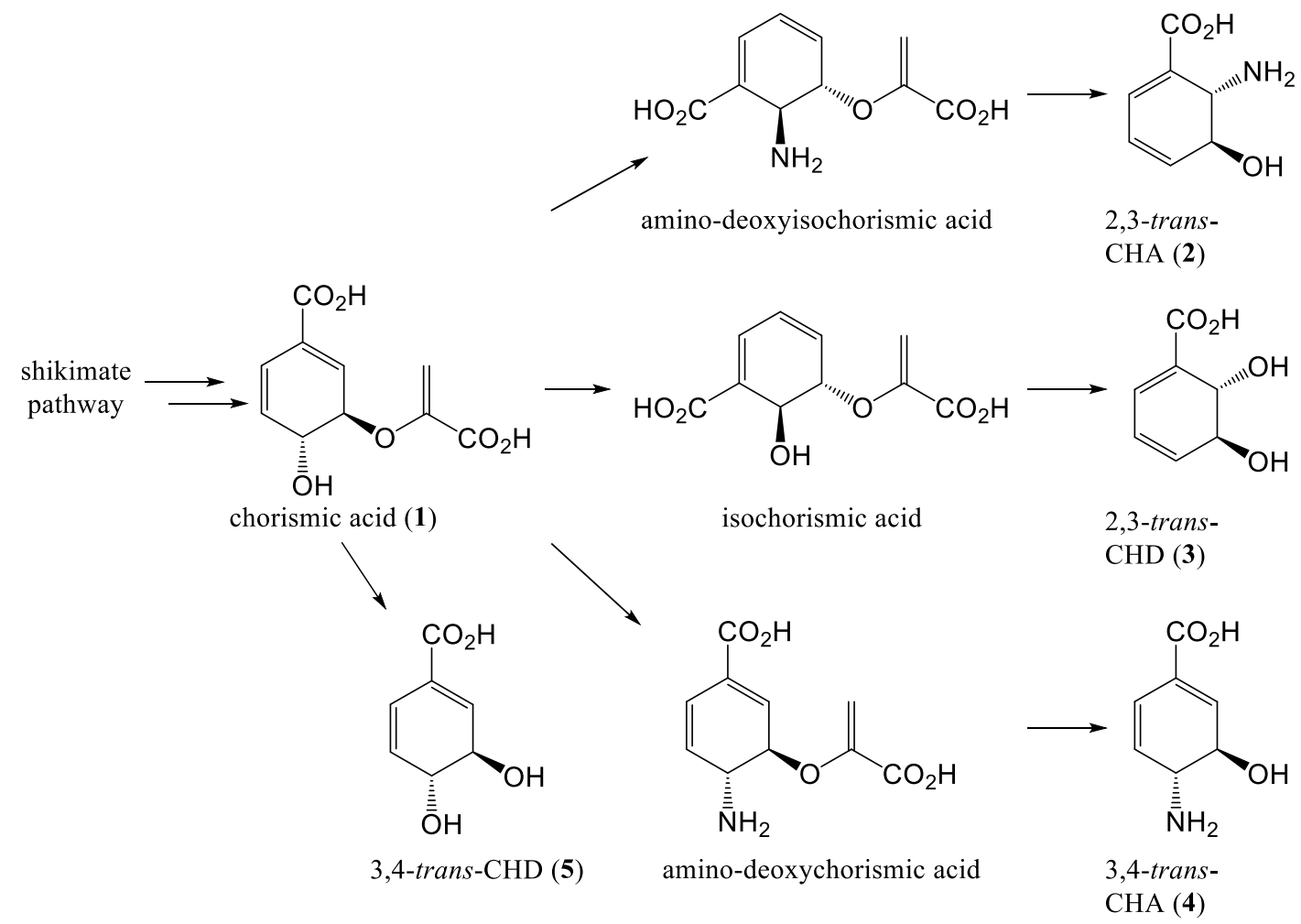

Scheme 1. Amino acids and 1,2-diol metabolites derived from chorismic acid (1) as a branching point. $^{33}$

Compounds $\mathbf{2}$ and $\mathbf{4}$ are metabolites of the shikimate biosynthetic pathway (Scheme 1). Microbial access to 2 was realized by heterologous expression of phzDE in $E$. coli cells, which allowed the production of up to $12 \mathrm{~g} \cdot \mathrm{L}^{-1}$ of $2 .^{33,43}$ By using a $300-\mathrm{L}$ fed-batch culture approach, 2 was produced on a $\mathrm{kg}$ scale. ${ }^{44}$ Isolation of $\mathbf{2}$ was performed by concentration of the cell-free fermentation broth and crystallization from water at $4{ }^{\circ} \mathrm{C}$.

A concentration of $1.7 \mathrm{~g} \cdot \mathrm{L}^{-1}$ of 3,4-trans-CHA (4) was obtained by combining the pabAB gene and $p h z D$ gene in a recombinant $E$. coli strain. ${ }^{33,45}$ Amino acid $\mathbf{4}$ was isolated from the fermentation broth by cation-exchange chromatography.

Preparation of the zinc complexes 8-10 was carried out according to the procedure of Darbre and Machuqueiro (Scheme 2). ${ }^{46}$ 
$2 \mathrm{NH}_{\mathrm{NH}}^{\mathrm{OH}}+\mathrm{Zn}(\stackrel{\ominus}{\mathrm{O}} \stackrel{\mathrm{O}}{\mathrm{O}})_{2} \frac{\mathrm{TEA}}{\mathrm{MeOH}} \mathrm{Zn}\left({ }_{\mathrm{NH}}^{\mathrm{O}}\right)_{2}^{\Theta}+2 \mathrm{HOAc}$

6

7

8

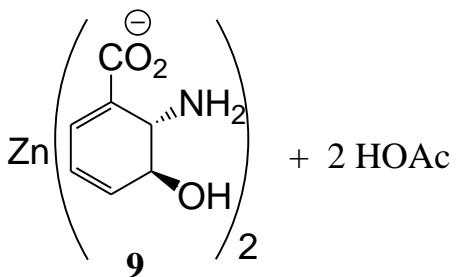

2

7
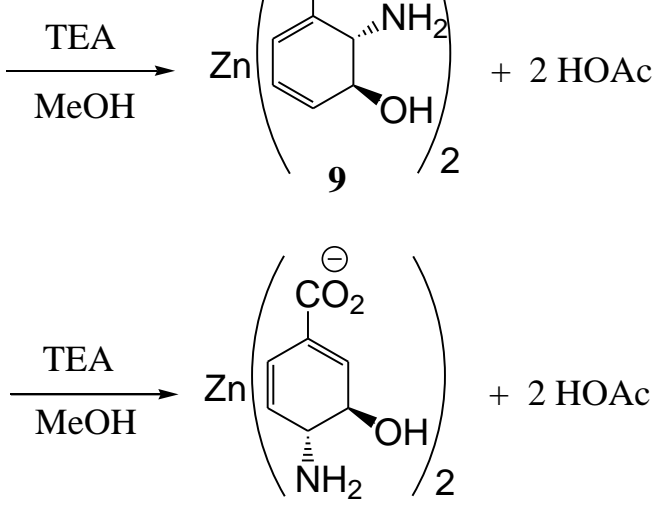

2<smiles>N[C@H]1C=CC(C(=O)O)=C[C@H]1O</smiles>

4<smiles>[Z][R10](C)(C)OC(=O)CCC</smiles>

7

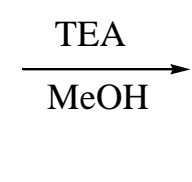

Scheme 2. Synthesis of the zinc complexes 8-10 of L-proline (6), 2,3-trans-CHA (2), and 3,4-trans-CHA (4).

The zinc complexes 8-10, which precipitated from the reaction mixtures and were sufficiently pure for use without the need for further purification steps, were obtained in 52-84\% yield. These complexes were tested in the asymmetric aldol addition reaction of acetone and $p$ nitrobenzaldehyde (see below).

The Knoevenagel condensation of dimethyl malonate (11) and 3-methylbutyraldehyde (12) was tested using L-proline (6), as well as the two amino acids $\mathbf{2}$ and $\mathbf{4}$. In the case of L-proline (6), the reaction was carried out using $13 \mathrm{~mol} \%$ of the catalyst, and the product $\mathbf{1 3}$ was obtained in $97 \%$ chemical yield (Scheme 3 ).

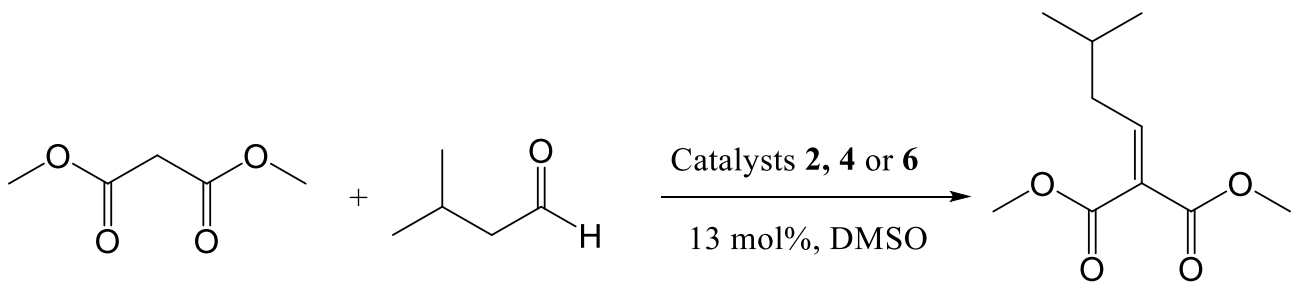

11

12

13

Scheme 3. Knoevenagel condensation using L-proline (6), 2,3-trans-CHA (2), and 3,4-transCHA (4) as catalysts (13 mol\%). 
The transformation using 2,3-trans-CHA (2) and 3,4-trans-CHA (4) was achieved by employing similar reaction conditions. In this case, the product 13 was obtained in $61 \%$ and $46 \%$ yield, respectively, clearly showing that the $\beta$ - and $\delta$-amino acids can be used as catalysts in the Knoevenagel condensation.

Intermolecular aldol condensation of acetone (15) and $p$-nitrobenzaldehyde (14) was achieved in the presence of a catalytic amount (5 mol\%) of $\mathrm{Zn}$ (L-proline) 2 complex (8) (Table 1, entry 1). After 4 hours, there was $83 \%$ conversion, and $(S)-\mathbf{1 6}$ was obtained in $11 \%$ ee (as determined by chiral-phase HPLC).

Table 1. Intermolecular aldol addition reaction of $p$-nitrobenzaldehyde (14) and acetone (15)

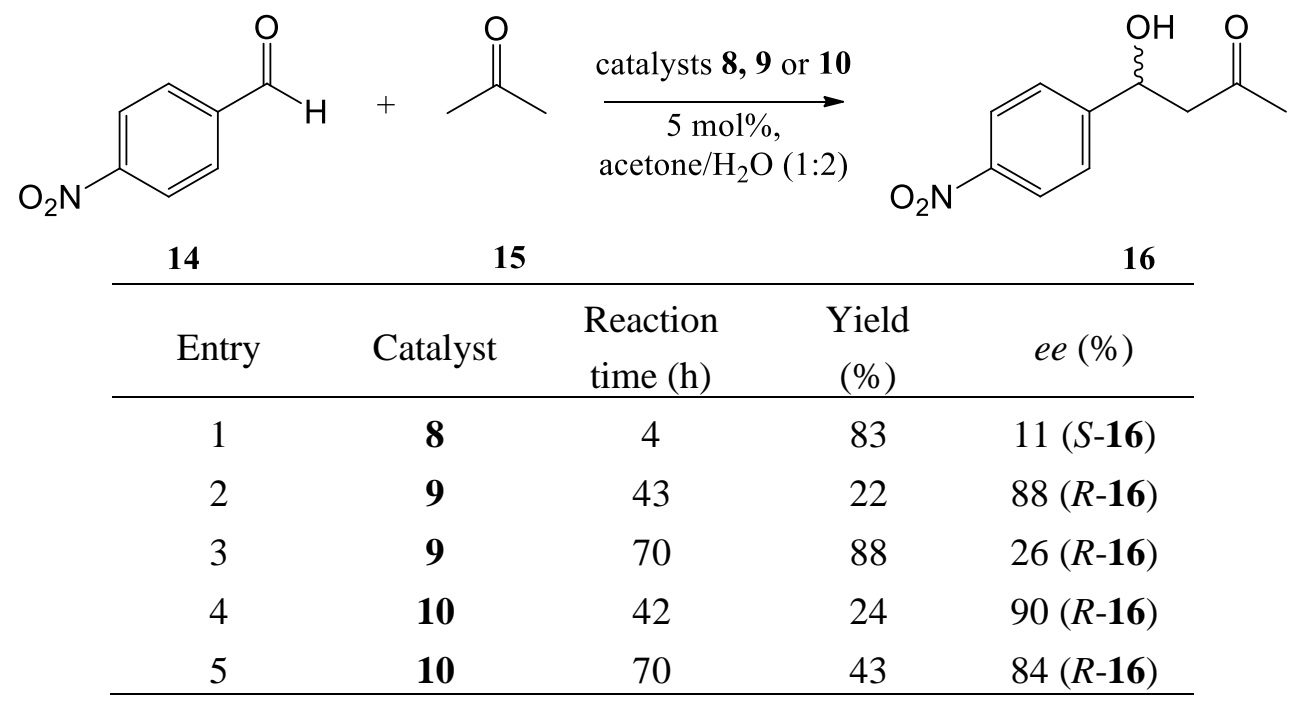

The reaction of $\mathbf{1 4}$ and $\mathbf{1 5}$ was carried out under similar conditions with complexes $\mathbf{9}$ and $\mathbf{1 0}$. We observed that the $e e$ of the product 16 depends on two factors: the conversion and the reaction time. In the presence of $\mathrm{Zn}(2,3-\text { trans-CHA })_{2}$ complex (9), the transformation showed a low yield of $22 \%$ with a high $e e$ of $88 \%$ after 43 hours; after 70 hours, the conversion increased to $88 \%$ and the ee decreased to $26 \%$ (Table 1, entries 2,3). The conversion continued to increase and the ee to decrease with increasing reaction time. We observed similar results in the case of $\mathrm{Zn}(3,4-$ transCHA) 2 complex (10). A conversion of $24 \%$ with $90 \%$ ee was observed after 42 hours; after 70 hours, the conversion increased to $43 \%$ and the ee decreased to $84 \%$ (Table 1, entries 4, 5). For both catalysts 9 and 10, the $(R)$-enantiomer of the aldol product $\mathbf{1 6}$ was obtained predominantly, which nicely complements the $S$-selectivity of the L-proline-derived complex 8. A similar dependency of the enantiomeric excess on reaction time (or catalyst loading) has recently been described by Gröger, Berkessel and co-workers. ${ }^{47}$

No product formation was detected when the aldol reaction was carried out using 2,3-transCHA (2) or 3,4-trans-CHA (4) in the pure forms. Also, the condensation product (elimination of water with formation of the $\alpha, \beta$-unsaturated ketone) was not observed. 
Our results confirm that amino acids, irrespective of the position of the amino group ( $\alpha-$, $\beta$ and $\delta$-amino acids were tested in parallel), are valuable chiral (organo)catalysts. While the two amino acids 2,3-trans-CHA (2) and 3,4-trans-CHA (4) proved to be just as good as the L-proline catalyst with respect to enantioselectivity, they intrinsically possess several advantages. As we and others have shown for $\mathbf{2}$ and 4, and for the respective diols 2,3-trans-CHD (3) and 3,4-trans-CHD (5) ${ }^{39,41,48,49}$ the carboxylate moiety and the vicinal diol or amino alcohol moieties can be protected selectively. The 1,3-diene system of these compounds can be modified highly specifically through oxidative or reductive processes (e.g., epoxidation, dihydroxylation, selective hydrogenation), as well as via pericyclic reactions such as Diels-Alder and hetero-Diels-Alder additions (Scheme 5).

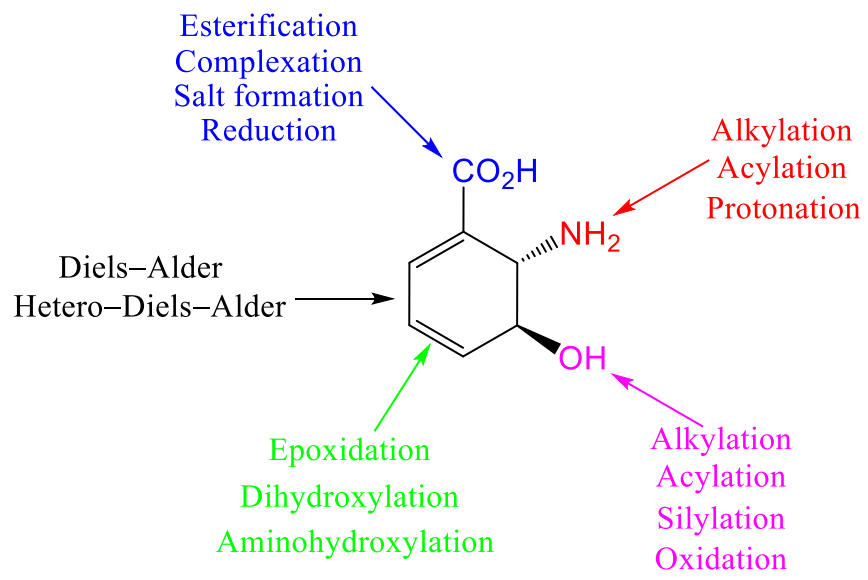

Scheme 5. The diversity of the possible modifications of 2,3-trans-CHA (2).

In the case of proline (6), modification of the amino and carboxylate groups, as well as hydroxylation at C3 and C4, is restricted. Recently, Al-Momani and Lataifeh have studied the efficiency of some proline modifications and the resulting catalytic behavior in aldol reactions. ${ }^{50}$ Hence, the catalysts $\mathbf{2}$ and $\mathbf{4}$ and derivatives thereof should be able to be tailored specifically and optimized with respect to selectivity and reactivity through the adjustment of steric or electronic effects. Moreover, these amino acids are natural products, easily accessible on a large scale starting from renewable resources. Thus, the diversity-oriented aspects of chorismate in biosynthesis have been successfully transferred to the diversity-oriented application of its derivatives in synthesis and catalysis.

\section{Experimental Section}

General. All reagents used were of analytical grade. ${ }^{1} \mathrm{H}$ NMR spectra were recorded on an AMX 300 or DRX 400 instrument (Bruker Physik AG, Germany) with $\mathrm{CD}_{3} \mathrm{OH}(\delta 4.87 \mathrm{ppm}), \mathrm{CHCl}_{3}(\delta$ $7.27 \mathrm{ppm})$ or HDO ( $\delta 4.81 \mathrm{ppm})$ as internal standard; ${ }^{13} \mathrm{C}$ NMR spectra were calibrated with ${ }^{13} \mathrm{CD}_{3} \mathrm{OD}(\delta 49.1 \mathrm{ppm}),{ }^{13} \mathrm{CDCl}_{3}(\delta 77.2 \mathrm{ppm})$ or sodium 3-(trimethylsilyl)-1-propanoate as 
internal standard. Enantiomeric excesses were determined by chiral-phase HPLC [Chiralpak AS, Daicel; eluent: 2-propanol/hexane (30:70); flow rate: $1.0 \mathrm{~mL} / \mathrm{min}$; detection: UV $254 \mathrm{~nm}$ ].

\section{Isolation and purification of cyclohexadiene acids 2 and 4}

(5S,6S)-6-Amino-5-hydroxycyclohexa-1,3-dienecarboxylic acid (2,3-trans-CHA, 2). The cellfree fermentation broth (LB or SOC medium) ${ }^{33}$ was concentrated at $60{ }^{\circ} \mathrm{C}$ by rotary evaporation (>10 g/L of 2), and further dried in vacuo. The brownish residue was washed with cold methanol and crystallized from water at $4{ }^{\circ} \mathrm{C}$. A yield of $80 \%$ (purity $>95 \%$ ) of the product $2(\mathrm{mp} 185-188$ $\left.{ }^{\circ} \mathrm{C}\right)$ was obtained. ${ }^{1} \mathrm{H}$ NMR $\left(\mathrm{CD}_{3} \mathrm{OD}, 300 \mathrm{~K}, \mathrm{ppm}\right): \delta 4.28(\mathrm{~d}, J=5.7 \mathrm{~Hz}, 1 \mathrm{H}), 4.46(\mathrm{dd}, J=5.7$, $4.6 \mathrm{~Hz}, 1 \mathrm{H}), 6.22(\mathrm{dd}, J=9.5,4.6 \mathrm{~Hz}, 1 \mathrm{H}), 6.34(\mathrm{dd}, J=9.5,5.7 \mathrm{~Hz}, 1 \mathrm{H}), 7.01(\mathrm{~d}, J=5.7 \mathrm{~Hz}, 1 \mathrm{H})$. ${ }^{13} \mathrm{C}$ NMR $\left(\mathrm{CD}_{3} \mathrm{OD}, 300 \mathrm{~K}, \mathrm{ppm}\right): \delta 51.9,66.0,125.7,128.1,130.5,132.8,173.0$.

\section{$\mathbf{( 3 R , 4 R ) - 4 - A m i n o - 3 - h y d r o x y c y c l o h e x a - 1 , 5 - d i e n e c a r b o x y l i c ~ a c i d ~ ( 3 , 4 - t r a n s - C H A , ~ 4 ) ~}$}

Cell-free fermentation broth (200 mL LB or SOC medium) ${ }^{33}$ was basified by addition of aqueous sodium hydroxide $(2 \mathrm{M}, 10 \mathrm{~mL})$. The turbid liquid was centrifuged, and the supernatant was passed through a column with ion-exchange resin (Dowex $50 \mathrm{WX} 8, \mathrm{H}^{+}$form). The column was washed with water $(300 \mathrm{~mL})$ and 4 eluted with $0.5 \mathrm{M} \mathrm{NH}_{3}$. The product-containing solution was lyophilized; $350 \mathrm{mg}$ of a white powder containing $14 \%$ of compound 4 (by comparison with internal standard in the ${ }^{1} \mathrm{H}$ NMR spectrum) was obtained as the main NMR-active compound. ${ }^{1} \mathrm{H}$ NMR ( $\left.\mathrm{D}_{2} \mathrm{O}, 300 \mathrm{~K}, \mathrm{ppm}\right): \delta 4.13(\mathrm{dt}, J=11.2,2.7 \mathrm{~Hz}, 1 \mathrm{H}), 4.67(\mathrm{dd}, J=11.2,3.5 \mathrm{~Hz}, 1 \mathrm{H}), 5.96$ $(\mathrm{dd}, J=10.0,3.2 \mathrm{~Hz}, 1 \mathrm{H}), 6.57(\mathrm{~d}, J=10.0 \mathrm{~Hz}, 1 \mathrm{H}), 6.83(\mathrm{~m}, 1 \mathrm{H}) .{ }^{13} \mathrm{C}$ NMR $\left(\mathrm{D}_{2} \mathrm{O}, 300 \mathrm{~K}, \mathrm{ppm}\right)$ : $\delta 52.8,67.8,122.7,125.0,128.5,138.2,168.0$.

\section{Preparation of the zinc complexes 8-10}

Zn(L-proline)2 complex (8). L-Proline (6; $499 \mathrm{mg}$, $4.34 \mathrm{mmol}$ ) was dissolved in $\mathrm{MeOH}$ (30 mL), then TEA $(0.6 \mathrm{~mL}, 4.34 \mathrm{mmol})$ was added. The mixture was stirred at $\mathrm{rt}$ for $10 \mathrm{~min}$, then zinc acetate $(7 ; 476 \mathrm{mg}, 2.17 \mathrm{mmol})$ was added. A colorless precipitate appeared immediately. After the mixture was stirred for $1 \mathrm{~h}$, the solid material was collected by filtration and dried under vacuum to give $\mathrm{Zn}$ (L-proline) $)_{2}$ complex (8); yield: $532 \mathrm{mg}(84 \%) .{ }^{1} \mathrm{H}$ NMR $\left(\mathrm{D}_{2} \mathrm{O}, 300 \mathrm{~K}, \mathrm{ppm}\right): \delta$ 1.87 (bs, 3H), 2.29 (bm, 1H), 3.04 (bs, 1H), 3.19 (bm, 1H), 3.92 (bs, 1H).

Zn(2,3-trans-CHA)2 complex (9). 2,3-trans-CHA (2; $350 \mathrm{mg}, 2.26 \mathrm{mmol}$ ) was dissolved in $\mathrm{MeOH} / \mathrm{H}_{2} \mathrm{O}(1: 1,30 \mathrm{~mL})$, then TEA $(312 \mu \mathrm{L}, 2.27 \mathrm{mmol})$ was added. The mixture was stirred at rt for $10 \mathrm{~min}$, then zinc acetate $(7 ; 248 \mathrm{mg}, 1.13 \mathrm{mmol})$ was added. After the mixture was stirred for $1 \mathrm{~h}$, the solid material was removed by filtration. After $3 \mathrm{~h}$, a white solid precipitated from the filtrate. The precipitate was separated and dried under vacuum to give $\mathrm{Zn}(2,3 \text {-trans-CHA })_{2}$ complex (9); yield: $244 \mathrm{mg}(58 \%) .{ }^{1} \mathrm{H}$ NMR (D $\left.2 \mathrm{O}, 300 \mathrm{~K}, \mathrm{ppm}\right): \delta 3.98$ (bs, $\left.1 \mathrm{H}\right), 4.33$ (bs, 1H), 6.22 (bm, 1H), 6.34 (bm, 1H), 6.92 (bm, 1H).

Zn(3,4-trans-CHA)2 complex (10). 3,4-trans-CHA (4; $167 \mathrm{mg}, 1.08 \mathrm{mmol})$ was dissolved in $\mathrm{MeOH}(7 \mathrm{~mL})$. The same amount of water was added to obtain a clear solution. This was followed by addition of TEA $(150 \mu \mathrm{L}, 1.08 \mathrm{mmol})$. The mixture was stirred at $\mathrm{rt}$ for $10 \mathrm{~min}$, then zinc acetate (7; $119 \mathrm{mg}, 0.54 \mathrm{mmol}$ ) was added. After the mixture was stirred for $1 \mathrm{~h}$, the solid material was removed by filtration. From the filtrate, a white solid precipitated after addition of TEA $(240 \mu \mathrm{L})$. 
The precipitate was separated and dried under vacuum to give $\mathrm{Zn}(3,4-$ trans-CHA) 2 complex (10); yield: $104 \mathrm{mg}(52 \%) .{ }^{1} \mathrm{H}$ NMR $\left(\mathrm{D}_{2} \mathrm{O}, 300 \mathrm{~K}, \mathrm{ppm}\right): \delta 4.01$ (bm, 1H), 4.56-4.60 (bm, 1H), 5.895.92 (bm, 1H), 6.51-6.54 (bm, 2H).

\section{Knoevenagel condensations}

With L-proline (6). 3-Methylbutyraldehyde (12; $172 \mu \mathrm{L}, 1.55 \mathrm{mmol})$ was dissolved in DMSO (10 $\mathrm{mL})$. L-Proline $(\mathbf{6} ; 23 \mathrm{mg}, 0.2 \mathrm{mmol})$ was added and, after $5 \mathrm{~min}$, dimethyl malonate $(\mathbf{1 1} ; 459 \mu \mathrm{L}$, $4.00 \mathrm{mmol}$ ) was added. The mixture was stirred at rt overnight, then diluted with ethyl acetate (20 $\mathrm{mL})$, and washed twice with water $(2 \times 20 \mathrm{~mL})$. The organic layer was dried over anhydrous $\mathrm{Na}_{2} \mathrm{SO}_{4}$ and concentrated to give dimethyl 2-(3-methylbutylidene)malonate (13); yield: $297 \mathrm{mg}$ (97\%). ${ }^{1} \mathrm{H}$ NMR (400 MHz, $298 \mathrm{~K}, \mathrm{ppm}$, in $\left.\mathrm{CDCl}_{3}\right): \delta 7.07(\mathrm{t}, J=7.9 \mathrm{~Hz}, 1 \mathrm{H},=\mathrm{CH}), 3.84(\mathrm{~s}, 3 \mathrm{H}$, $\left.\mathrm{OCH}_{3}\right), 3.80\left(\mathrm{~s}, 3 \mathrm{H}, \mathrm{OCH}_{3}\right), 2.21\left(\mathrm{dd}, J=6.9 \mathrm{~Hz}, J=7.8 \mathrm{~Hz}, 2 \mathrm{H}, \mathrm{CH}_{2}\right), 1.83\left(\mathrm{~m}, 1 \mathrm{H}, \mathrm{CH}\left(\mathrm{CH}_{3}\right)_{2}\right)$, $0.96\left(\mathrm{~s}, 3 \mathrm{H}, \mathrm{CH}_{3}\right), 0.95\left(\mathrm{~s}, 3 \mathrm{H}, \mathrm{CH}_{3}\right)$.

With 2,3-trans-CHA (2). Aldehyde 12 (172 $\mu \mathrm{L}, 1.55 \mathrm{mmol})$ was dissolved in DMSO (10 mL). 2,3-trans-CHA (2; $31 \mathrm{mg}, 0.2 \mathrm{mmol})$ was added and, after $5 \mathrm{~min}$, dimethyl malonate $(\mathbf{1 1} ; 459 \mu \mathrm{L}$, $4.00 \mathrm{mmol}$ ) was added. The mixture was stirred at rt overnight, then diluted with ethyl acetate (20 $\mathrm{mL})$ and washed twice with water $(2 \times 20 \mathrm{~mL})$. The organic layer was dried over anhydrous $\mathrm{Na}_{2} \mathrm{SO}_{4}$ and concentrated to give product 13; yield: $188 \mathrm{mg}(61 \%)$.

With 3,4-trans-CHA (4). In a similar transformation of aldehyde 12 and malonate 11 with 3,4trans-CHA (4) as catalyst, the product 13 was obtained in $46 \%$ yield after a $70 \mathrm{~h}$ reaction time.

\section{Aldol Additions}

With Zn(L-proline)2 complex (8). p-Nitrobenzaldehyde (14; $151 \mathrm{mg}, 1.0 \mathrm{mmol}$ ) was dissolved in acetone $(\mathbf{1 5}, 5 \mathrm{~mL})$. A solution of $\mathrm{Zn}$ (L-proline) 2 complex $(\mathbf{8} ; 15 \mathrm{mg}, 0.05 \mathrm{mmol})$ in water $(10$ $\mathrm{mL}$ ) was added and the mixture was stirred under inert conditions $\left(\mathrm{N}_{2}\right)$. After $4 \mathrm{~h}$, the mixture was concentrated and the residue was dissolved in chloroform $(20 \mathrm{~mL})$. The insoluble material was removed by filtration. The filtrate was concentrated by rotatory evaporation to give 4-hydroxy-4(4-nitrophenyl)butan-2-one (S-16); yield: $173 \mathrm{mg}(83 \%) ; 11 \%$ ee of the $S$-isomer. The ee was determined by chiral-phase HPLC; $(R)-\mathbf{1 6}, t_{\mathrm{R}}=13.7 \mathrm{~min} ;(S)-\mathbf{1 6}, t_{\mathrm{R}}=17.8 \mathrm{~min} .{ }^{1} \mathrm{H} \mathrm{NMR}\left(\mathrm{CDCl}_{3}\right.$, $300 \mathrm{~K}, \mathrm{ppm}): \delta 2.23$ (s, 3H), $2.86(\mathrm{~m}, 2 \mathrm{H}), 3.61$ (bs, $1 \mathrm{H}, \mathrm{OH}), 5.28$ (dd, J=7.7, $4.6 \mathrm{~Hz}, 1 \mathrm{H}), 7.55$ $(\mathrm{d}, J=9.1 \mathrm{~Hz}, 2 \mathrm{H}), 8.22(\mathrm{~d}, J=9.1 \mathrm{~Hz}, 2 \mathrm{H}) .{ }^{13} \mathrm{C} \mathrm{NMR}\left(\mathrm{CDCl}_{3}, 300 \mathrm{~K}, \mathrm{ppm}\right): \delta 30.9\left(\mathrm{CH}_{3}\right), 51.7$ $\left(\mathrm{CH}_{2}\right), 69.1(\mathrm{CH}), 124.0(2 \times \mathrm{CH}), 126.6(2 \times \mathrm{CH}), 150.1\left(2 \times \mathrm{C}_{\mathrm{q}}\right), 208.8(\mathrm{C}=\mathrm{O})$.

With Zn(2,3-trans-CHA)2 complex (9). A similar transformation was undertaken with $\mathrm{Zn}(2,3$ trans-CHA $)_{2}$ complex $(\mathbf{9} ; 18.8 \mathrm{mg}, 0.05 \mathrm{mmol})$ as catalyst. After $70 \mathrm{~h}$, the filtrate was concentrated by rotatory evaporation to give $(R)-16$; yield: $184 \mathrm{mg}(88 \%) ; 26 \%$ ee. The $e e$ of the product showed a dependence on the reaction time and conversion. After a reaction time of $43 \mathrm{~h}$ ( $22 \%$ conversion), the product was highly enantioenriched $[88 \%$ ee, $(R)-\mathbf{1 6}]$.

With Zn(3,4-trans-CHA)2 complex (10). A similar transformation was undertaken with $\mathrm{Zn}(3,4$ trans-CHA) 2 complex $(\mathbf{1 0} ; 18.8 \mathrm{mg}, 0.05 \mathrm{mmol})$ as catalyst. After $70 \mathrm{~h}$, the filtrate was concentrated by rotatory evaporation to give $(R)$-16; yield: $90 \mathrm{mg}(43 \%) ; 84 \%$ ee. The $e e$ of the product showed a dependence on the reaction time and conversion. After a reaction time of $42 \mathrm{~h}$ ( $24 \%$ conversion), the product was highly enantioenriched [90\% ee, $(R)-\mathbf{1 6}]$. 


\section{Acknowledgements}

Lo'ay Al-Momani would like to thank DFG and DAAD for their financial support of his residence in Germany, as well as the Tafila Technical University (TTU) for travel support. This work was financially supported by the German Federal Ministry of Education and Research (BMBF) as part of the CHORUS (BMBF 0312688) project.

\section{References}

1. Wöhler, F.; Liebig, J. Ann. Pharm. 1832, 3, 249. https://doi.org/10.1002/jlac.18320030302

2. Fischer, E. Justus Liebigs Ann. Chem. 1882, 211, 214. https://doi.org/10.1002/jlac.18822110204

3. Dakin, H. D. J. Biol. Chem. 1909, 7, 49.

4. Langenbeck, W. Angew. Chem. 1932, 45, 97. https://doi.org/10.1002/ange.19320450502

5. Langenbeck, W.; Hutschenreuter, R. Z. Anorg. Allg. Chem. 1930, 188, 1. https://doi.org/10.1002/zaac.19301880102

6. Prout, F. S. J. Org. Chem. 1953, 18, 928. https://doi.org/10.1021/jo50014a005

7. Eder, U.; Sauer, G.; Wiechert, R. Angew. Chem. Int. Ed. Engl. 1971, 10, 496. https://doi.org/10.1002/anie.197104961

8. Hajos, Z. G.; Parrish, D. R. J. Org. Chem. 1974, 39, 1615. https://doi.org/10.1021/jo00925a003

9. Jarvo, E. R.; Miller, S. T. Tetrahedron 2002, 58, 2481. https://doi.org/10.1016/S0040-4020(02)00122-9

10. Sutar, R. L.; Joshi, N. N. Tetrahedron: Asymmetry 2013, 24, 43 and references cited therein. https://doi.org/10.1016/j.tetasy.2012.11.018

11. Ahrendt, K. A.; Borths, C. J.; MacMillan, W. C. J. Am. Chem. Soc. 2000, 122, 4243. https://doi.org/10.1021/ja000092s

12. List, B. Tetrahedron 2002, 58, 5573. https://doi.org/10.1016/S0040-4020(02)00516-1

13. List, B.; Pojarliev, P.; Castello, C. Org. Lett. 2001, 3, 573. https://doi.org/10.1021/o1006976y

14. Notz, W.; List, B. J. Am. Chem. Soc. 2000, 122, 7386. https://doi.org/10.1021/ja001460v

15. Sakthivel, K.; Notz, W.; Bui, T.; Barbas III, C. F. J. Am. Chem. Soc. 2001, 123, 5260. https://doi.org/10.1021/ja010037z 
16. Schmid, M. B.; Zeitler, K.; Gschwind, R. M. Angew. Chem. Int. Ed. 2010, 49, 4997. https://doi.org/10.1002/anie.200906629

17. Hoang, L.; Bahmanyar, S.; Houk, K. N.; List, B. J. Am. Chem. Soc. 2003, 125, 16. https://doi.org/10.1021/ja028634o

18. List, B.; Lerner, R. A.; Barbas III, C. F. J. Am. Chem. Soc. 2000, 122, 2395. https://doi.org/10.1021/ja994280y

19. Notz, W.; Tanaka, F.; Barbas III, C. F. Acc. Chem. Res. 2004, 37, 580. https://doi.org/10.1021/ar0300468

20. Cordova, A.; Notz, W.; Zhong, G.; Betancort, J. M.; Barbas III, C. F. J. Am. Chem. Soc. 2002, 124, 1842. https://doi.org/10.1021/ja017270h

21. Kober, R.; Papadopoulus, K.; Miltz, W.; Enders, D.; Steglich, W. Tetrahedron 1985, 41, 1693. https://doi.org/10.1016/S0040-4020(01)96483-X

22. Xu, L.-W.; Lu, Y. Org. Biomol. Chem. 2008, 6, 2047. https://doi.org/10.1039/b803116a

23. Bisai, V.; Bisai, A.; Singh, V. K. Tetrahedron 2012, 68, 4541. https://doi.org/10.1016/j.tet.2012.03.099

24. Heravi, M. M.; Asadi, S. Tetrahedron: Asymmetry 2012, 23, 1431. https://doi.org/10.1016/j.tetasy.2012.10.002

25. Duan, J.; Li, P. Catal. Sci. Technol. 2014, 4, 311. https://doi.org/10.1039/C3CY00739A

26. Amedjkouh, M. Tetrahedron: Asymmetry 2005, 16, 1411. https://doi.org/10.1016/j.tetasy.2005.02.031

27. Amedjkouh, M. Tetrahedron: Asymmetry 2007, 18, 390. https://doi.org/10.1016/j.tetasy.2007.01.025

28. Morcillo, M.; North, M.; Villuendas, P. Synthesis 2011, 1918.

29. Bhowmick, S.; Bhowmick, K. C. Tetrahedron: Asymmetry 2011, 22, 1945 and references cited therein. https://doi.org/10.1016/j.tetasy.2011.11.009

30. Bassan, A.; Zou, W.; Reyes, E.; Himo, F.; Cordova, A. Angew. Chem. Int. Ed. 2005, 44, 7028. https://doi.org/10.1002/anie.200502388

31. Cordova, A.; Zou, W.; Dziedzic, P.; Ibrahem, I.; Reyes, E.; Xu, Y. Chem. Eur. J. 2006, 12, 5383. https://doi.org/10.1002/chem.200501639

32. Cordova, A.; Zou, W.; Ibrahem, I.; Reyes, E.; Engqvist, M.; Liao, W. W. Chem. Commun. 2005, 3586. https://doi.org/10.1039/b507968n 
33. Bongaerts, J.; Esser, S.; Lorbach, V.; Al-Momani, L.; Müller, M. A.; Franke, D.; Grondal, C.; Kurutsch, A.; Bujnicki, R.; Takors, R.; Raeven, L.; Wubbolts, M.; Bovenberg, R.; Nieger, M.; Schürmann, M.; Trachtmann, N.; Kozak, S.; Sprenger, G. A.; Müller, M. Angew. Chem. Int. Ed. 2011, 50, 7781, and its Supp. Info. https://doi.org/10.1002/anie.201103261

34. Heine, A.; DeSantis, G.; Luz, J.; Mitchell, G. M.; Wong, C.-H.; Wilson, I. A. Science 2001, 294, 369.

https://doi.org/10.1126/science.1063601

35. Haslam, E. Shikimic Acid: Metabolism and Metabolites, John Wiley \& Sons Ltd.: Chichester, 1993.

36. He, Z. K.; Lavoie, D. S.; Bartlett, P. A.; Toney, M. D. J. Am. Chem. Soc. 2004, 126, 2378. https://doi.org/10.1021/ja0389927

37. Li, W.; Xie, D.; Frost, J. W. J. Am. Chem. Soc. 2005, 127, 2874. https://doi.org/10.1021/ja045148n

38. Franke, D.; Sprenger, G. A.; Müller, M. Angew. Chem. Int. Ed. 2001, 40, 555. https://doi.org/10.1002/1521-3773(20010202)40:3<555::AID-ANIE555>3.0.CO;2-0

39. Franke, D.; Sprenger, G. A.; Müller, M. ChemBioChem 2003, 4, 775. https://doi.org/10.1002/cbic.200300601

40. Franke, D.; Lorbach, V.; Esser, S.; Dose, C.; Halfar, M.; Thömmes, J.; Müller, R.; Takors, R.; Sprenger,G. A.; Müller, M. Chem. Eur. J. 2003, 9, 4188. https://doi.org/10.1002/chem.200204265

41. Lorbach V.; Franke, D.; Nieger, M.; Müller, M. Chem. Commun. 2002, 494. https://doi.org/10.1039/b110420a

42. Lorbach, V.; Franke, D.; Esser, S.; Dose, C.; Sprenger, G. A.; Müller, M. Microbially Produced Functionalized Cyclohexadiene-trans-diols as a New Class of Chiral Building Blocks in Organic Synthesis: On the Way to Green and Combinatorial Chemistry, in Highlights in Bioorganic Chemistry, Eds. C. Schmuck, H. Wennemers, Wiley-VCH, Weinheim, 2004, pp. 511. https://doi.org/10.1002/3527603727.ch6d

43. McDonald, M.; Mavrodi, D. V.; Thomashow, L. S.; Floss, H. G. J. Am. Chem. Soc. 2001, 123, 9459. https://doi.org/10.1021/ja011243+

44. Bujnicki, R. Bioprozessentwicklung und in-situ Produktgewinnung von trans-CyclohexadienDerivaten, Technische Universität München, München, 2007.

45. Chang, Z.; Sun, Y.; He, J.; Vining, L. C. Microbiology 2001, 147, 2113. https://doi.org/10.1099/00221287-147-8-2113

46. Darbre, T.; Machuqueiro, M. Chem. Commun. 2003, 1090. https://doi.org/10.1039/b301117h

47. Rulli, G.; Duangdee, N.; Baer, K.; Hummel, W.; Berkessel, A.; Gröger, H. Angew. Chem. Int. Ed. 2011, 50, 7944 . https://doi.org/10.1002/anie.201008042

48. Bunagge, M. E.; Ganesh, T.; Masesane, I. B.; Orton, D.; Steel, P. G. Org. Lett. 2003, 5, 239. https://doi.org/10.1021/o10269704 
49. Masesane, I. B.; Steel, P. G. Tetrahedron Lett. 2004, 45, 5007. https://doi.org/10.1016/j.tetlet.2004.05.007

50. Al-Momani, L.; Lataifeh, A. Inorg. Chim. Acta 2013, 394, 176. https://doi.org/10.1016/j.ica.2012.07.015 